\title{
The Effect of Different Substrates on the Growth of Enterolobium contortisiliquum
}

\author{
A. Q. Batista ${ }^{1}$, Carla Figueiredo Coelho ${ }^{1,2}$, Ires Paula de Andrade Miranda ${ }^{1,3}$, Edelcílio Marques Barbosa ${ }^{1}$ \\ $\&$ Thiago de Paula de Andrade Miranda ${ }^{1}$ \\ ${ }^{1}$ Laboratório de Pesquisas em Palmeiras (LABPALM), Instituto Nacional de Pesquisas da Amazônia (INPA), \\ Manaus, Amazonas, Brazil \\ ${ }^{2}$ Postgraduate Program in Tropical Agronomy, Federal University of Amazonas, Manaus, Amazonas, Brazil \\ ${ }^{3}$ REDE PPG/BIONORTE Postgraduate Program, Manaus, Amazonas, Brazil \\ Correspondence: Carla Figueiredo Coelho, Laboratório de Pesquisas em Palmeiras (LABPALM), Instituto \\ Nacional de Pesquisas da Amazônia (INPA), Manaus, Amazonas, CEP: 69067375, Brazil. Tel: 55-92-9603-7995. \\ E-mail: carlacoelhofigueiredo@gmail.com
}

Received: December 14, 2017

doi:10.5539/jas.v10n3p197
Accepted: January 15, $2018 \quad$ Online Published: February 15, 2018

URL: https://doi.org/10.5539/jas.v10n3p197

\begin{abstract}
Brazilian origin species Enterolobium contortisiliquum (Vell.) Morong (Fabaceae) is distributed from north to south of the country. The species is a pioneer and important in the manufacture of furniture, boats and canoes, and presents easy handling also being significant for degraded areas recovery programs. As a result, management plans are necessary for the survival of this species. In the context of reforestation and recovery of degraded areas, the production of seedlings of native forest species occurs in nurseries and the quality of these plants depends on several factors, among which, the composition of the substrates is a factor of great importance for having its physical, chemical and biological characteristics directly linked to the growth of the seedlings. The study was based on obtaining knowledge and potential applicability in seedling production, subjecting it to different substrates, in order to evaluate their growth in height, diameter, number of leaves and biomass. The behavior presented by the species suggests its potential for reforestation turned to production and conservationism, since it revealed tolerance to the various types of substrates and better results with the use of organic matter added to the substrate.
\end{abstract}

Keywords: Amazon, dicotyledonous, substrate, growth, tropical

\section{Introduction}

Enterolobium contortisiliquum (Vell.) Morong (Fabaceae) is commonly known as tamboril, tamburé, monkey ear, timbaúva, timbó or black timbaúva. It is distributed throughout Brazil and also occurs in Bolivia, Paraguay, Argentina and Uruguay (Corandin, Siminski, \& Reis, 2011). The propagation mechanism of this species happens through seeds and also vegetatively. It is a heliophile species of rapid growth, rustic, with regenerative potential in degraded areas and suitable for reforestation areas. Its wood is light and soft, used mainly in the manufacture of canoes (boats), general caskets, toys and plywood. It is dispersed in several forest formations, occurring in the northern, central-western and southern areas of the country (Lorenzi, 2002).

In the context of reforestation and recovery of degraded areas, the production of seedlings of native forest species occurs in nursery and the quality of these plants is dependent on several factors, among which, the composition of the substrates is a factor of great importance for having their physical, chemical and biological characteristics directly linked to the growth of the seedlings (Oliveira, Accioly, Santos, Flores, \& Barbosa, 2014; Ferreira, Rocha, Gonçalves, Alves, \& Ribeiro, 2009).

In Brazil, the practice of liming is present in all quadrants of the country, commonly in areas with the predominance of yellow latosols. Generally, these soils are acidic, with low base saturation, with high exchangeable aluminum contents, hugely deep, small and have strong granular structure; however, it offers good yields when its fertility is corrected (Furtini Neto, Vale, Faquin, \& Fernandes, 1999; Silva, Tucci, Lima, Souza, \& Venturin, 2007; Tucci, Lima, \& Lessa, 2009). 
Most ground soils in the Amazon are featured by low fertility, high acidity, low cation exchange capacity and high aluminum saturation. These conditions can be harmful to most forest species. To correct low fertility and high acidity, fertilizers and limestones are required, which allow neutralization of aluminum and other undesirable soil characteristics (Zenero et al., 2016).

Organic fertilization is an alternative to the use of chemical fertilizers, as well as providing nutrients, improves soil aeration, enhances permeability, aggregate stability and water retention capacity, and decreases soil compaction (Oliveira et al., 2014) and good results can be obtained in the production of seedlings.

The use of organic materials, such as crop residues, industrial waste and animal manure, has been increasingly attracting farmers and technicians. This is due to the aforementioned advantages and the availability and easy access to these materials.

The sustainable cultivation of $E$. contortisiliquum under natural conditions requires studies related to silvicultural aspects, such as aspects of seedling production and monitoring. Favoring a greater possibility in the perpetuation of the species and establishment of progenies. The study aims to evaluate the initial growth of seedlings in function of different substrates.

\section{Methods}

\subsection{Place of Study}

The study was carried out in a greenhouse at the Department of Agricultural and Soil Engineering (DEAS) of the Faculty of Agrarian Sciences (FCA), Federal University of Amazonas (UFAM), located in the city of Manaus, AM, with Latitude South $03^{\circ} 06^{\prime} 05^{\prime \prime}$ and Longitude West of 59 $58^{\prime} 30.67^{\prime \prime}$, average elevation of $82 \mathrm{~m}$ asl.

\subsection{Installation of the Experiment to Monitor Seedlings}

Seeds were sown in sand, washed with $80 \%$ of germination, previously submitted to dormancy breaking by the seed (cutting) next to the seed, where the cotyledon (germinating part) is started, favoring the imbibition process (Brazil, 2009).

Twenty days after sowing, the most vigorous seedlings, with uniform height $(10 \mathrm{~cm})$, were transplanted individually into polyethylene bags with dimensions of $20 \times 30 \mathrm{~cm}$, containing three kilos of the following substrates:

$\mathrm{T} 1=$ Yellow Latosol

$\mathrm{T} 2=$ Yellow latosol with cattle manure $(2: 1)$

T3 = Yellow latosol with organic compound (2:1)

$\mathrm{T} 4=$ Yellow latosol with liming

The Yellow Latosol was collected in an area of secondary forest in the superficial layer of 0-20 cm of depth. Soon after the collection, the soil was dismantled and placed to dry in the open air for a period of 96 hours, after which it was passed through a $4 \mathrm{~mm}$ aperture mesh sieve.

The cattle manure used was tanned outdoors and dried and homogenized, being mixed uniformly to the soil. The dosage of manure corresponded to the proportion 2:1 by volume, being two parts of soil, for a part of dung, according to Carvalho Filho, J. Blank, and M. Blank (2004).

The organic compound was decomposed for six months, manufactured in the form of piles of one meter high by one meter wide. The components for the manufacture of organic compost contained in this work were: cattle manure, fruits, vegetables, pruning of grams, pruning of branches and fish waste, used in fairs and markets in the city of Manaus, Amazonas. The dosage of the compound corresponded to the ratio 2:1 by volume, being two parts of soil and one part of compound. The limestone dose was equal to $10.5 \mathrm{~g}$ of $\mathrm{CaCO}_{3}$ per experimental unit (CFSEMG, 1999).

\subsection{Parameters Evaluated}

The evaluated parameters were height, diameter and number of leaves during 84 days after the transplant of the seedlings; and ratio of dry shoot and root dry mass (MSPA/MSR) at the end of the experiment.

\subsection{Experimental Design and Statistical Analysis}

The experimental design was completely randomized, consisting of four treatments (substrates), with five replicates, each seedling being a replicate. Data regarding height, diameter and number of leaves were submitted to regression analysis. The data related to the biomass were submitted to analysis of variance and test of means 
by the test of Tukey to $5 \%$ of probability. The statistical program used was ASSISTAT Version 7.5 beta (2008) (Silva \& Azevedo, 2009).

\section{Results and Discussion}

Plant growth is dependent on changes in physiology, which can be measured by the rate of assimilation and/or plant morphology (Hunt, 1982). In this work, a morphological parameter was studied, measuring the diameter, height and number of leaves. Significant differences between treatments were verified from 42 days after transplanting.

E. contortisiliquum seedlings showed better results in number of leaves, height and diameter in the substrate Yellow Latosol with organic compost, followed by Yellow Latosol with cattle manure, Yellow Latosol with liming and only Latosol as substrate (Figures 1,2 and 3).

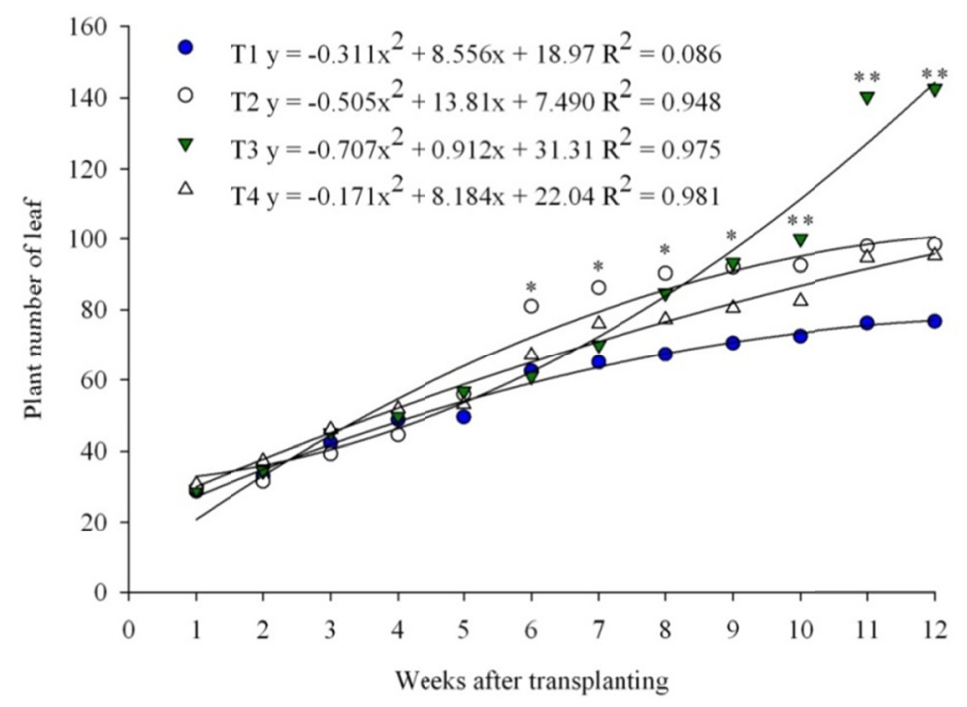

Figure 1. Number of leaves (E. contortisilicum, Fabaceae) in four treatments. T1: Yellow Latosol; T2: Yellow

Latosol + cattle manure (2:1); T3: Yellow Latosol + organic compound (2:1); T4: Yellow latosol + liming Note. ${ }^{* *}, *$ Significant at 1 and $5 \%$ probability, respectively.

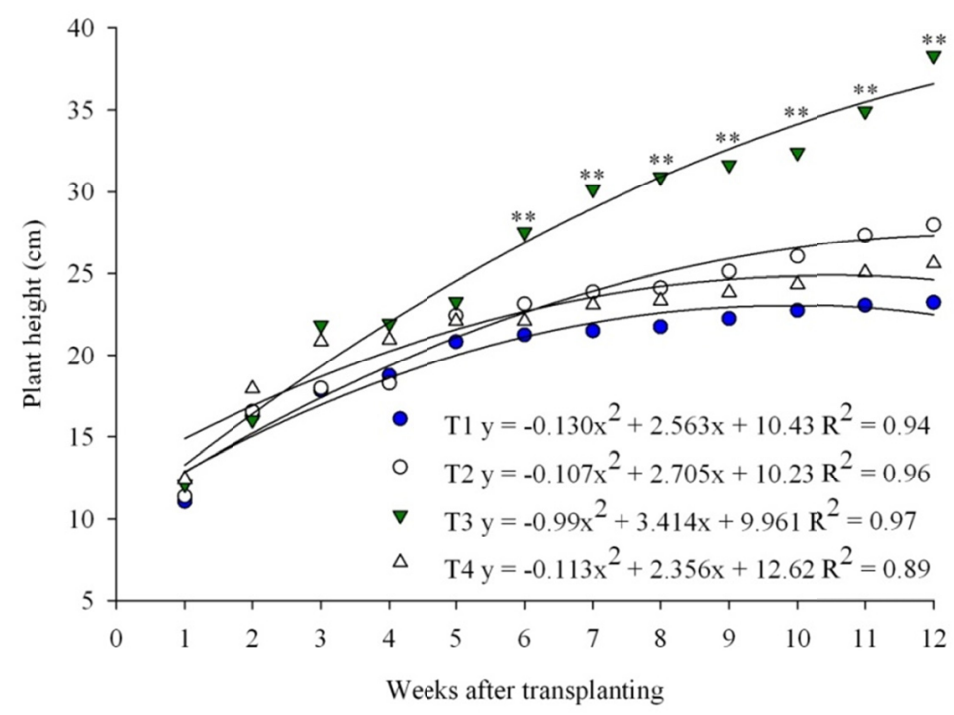

Figure 2. Height of seedlings (E. contortisiliquum, Fabaceae) in four treatments. T1: Yellow Latosol; T2: Yellow Latosol + cattle manure (2:1); T3: Yellow Latosol + organic compound (2:1); T4: Yellow latosol + liming

Note. ${ }^{* *}, *$ Significant at 1 and $5 \%$ probability, respectively. 


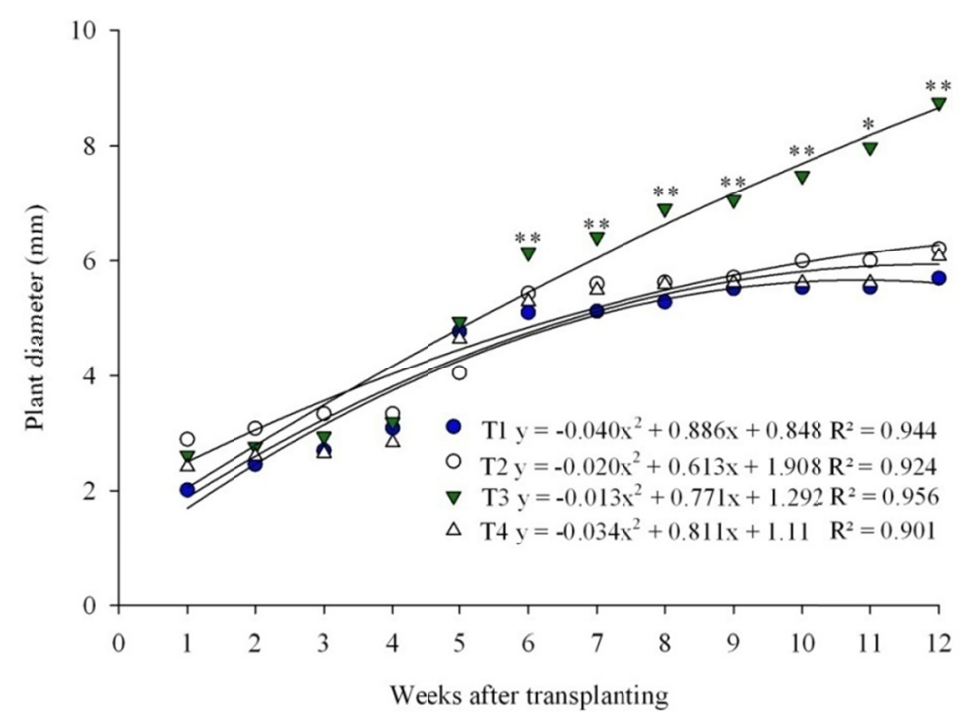

Figure 3. Diameter of seedlings (E. contortisiliquum, Fabaceae) in four treatments. T1: Yellow Latosol; T2: Yellow Latosol + cattle manure (2:1); T3: Yellow Latosol + organic compound (2:1); T4: Yellow latosol + liming Note. ${ }^{* *},{ }^{*}$ Significant at 1 and $5 \%$ probability, respectively.

The same result was found with respect to the accumulation of biomass, with the exception of the last two treatments, which did not differ statistically between them. It is possible to observe that there was a greater increase of biomass in the root with respect to the aerial part in the treatments with inferior results for the other parameters (Figure 4).

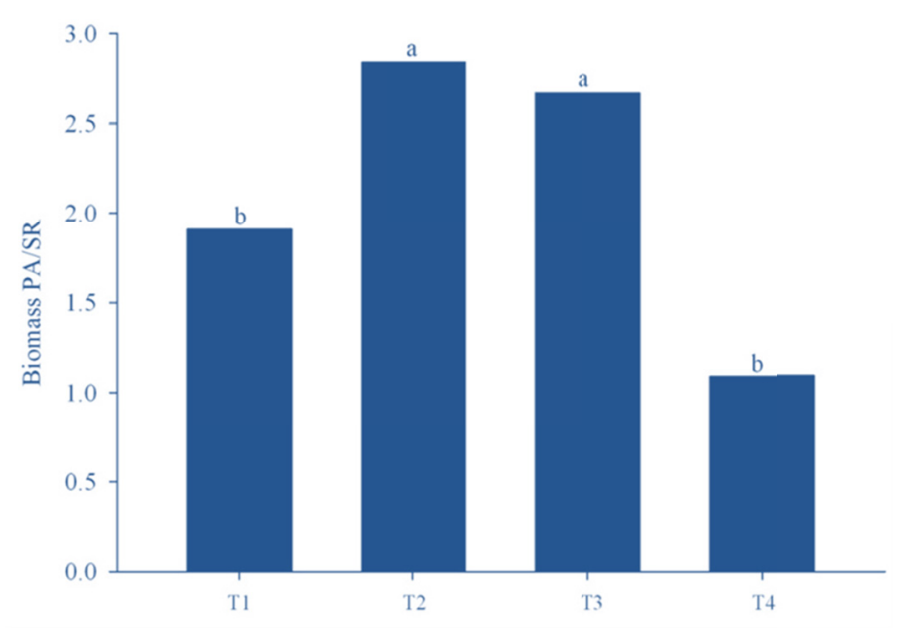

Figure 4. Allocation of biomass PA/SR (aerial part/root system) of E. contortisiliquum seedlings, Fabaceae, in four treatments. T1: Yellow Latosol; T2: Yellow Latosol + cattle manure (2:1); T3: Yellow Latosol + organic compound (2:1); T4: Yellow latosol + liming

Note. Equal letters do not differ statistically at the $5 \%$ probability level by the Tukey Test.

This result was expected by the lower presence of nutrients in the soil, confirmed by soil analysis (Tables 1 and 2). In a condition of nutrient deficiency, plants invest energy to develop the root system as a strategy to exploit a larger volume of soil to try to supply their nutritional demand (Carlos et al., 2014). 
Table 1. Result of chemical analysis of the substrates used in the production of Enterolobium contortisiliquum seedlings

\begin{tabular}{|c|c|c|c|c|c|c|c|c|c|c|c|c|}
\hline Substrates & pH $\mathrm{H}_{2} \mathrm{O}$ & C & M.O. & $\mathbf{P}$ & $\mathbf{K}$ & $\mathbf{C a}$ & Mg & Al & $\mathbf{H}+\mathbf{A l}$ & $\mathbf{t}$ & $T$ & $\mathbf{V}$ \\
\hline & & \multicolumn{2}{|c|}{---- $\mathrm{g} / \mathrm{dm}^{3}$} & \multicolumn{2}{|c|}{$--\mathrm{mg} / \mathrm{dm}^{3}--$} & $-\cdots$ & - & $---\mathrm{cm}$ & $\mathrm{l}_{\mathrm{c}} / \mathrm{dm}^{3}-$ & & ------ & $--\%--$ \\
\hline T1 & 4.37 & 32.5 & 55.9 & 13 & 21 & 0.27 & 0.08 & 2.16 & 10.07 & 2.58 & 10.5 & 4.02 \\
\hline T2 & 6.2 & 51.35 & 88.32 & 475 & 180 & 4.38 & 2.56 & 0 & 5.08 & 7.47 & 12.6 & 59.51 \\
\hline T3 & 5.58 & 76.97 & 132.4 & 79 & 300 & 5.08 & 1.88 & 0 & 6.98 & 7.81 & 14.8 & 52.82 \\
\hline T4 & 5.8 & 30.66 & 52.74 & 10 & 25 & 1.92 & 1.32 & 0 & 4.32 & 3.32 & 7.64 & 43.45 \\
\hline
\end{tabular}

Note. T1: Yellow Latosol; T2: Yellow Latosol + cattle manure (2:1); T3: Latosol yellow + organic compound (2:1); T4: Yellow latosol + liming.

Table 2. Average values for micronutrients, contained in the substrate used for seedling production of Enterolobium contortisiliquum

\begin{tabular}{lllcc}
\hline Substrates & Fe & Zn & Mn & Cu \\
\hline & ---10 & 0.96 & 0.56 \\
T1 & 102 & 1.65 & 24.9 & 2.19 \\
T2 & 93 & 3487 & 32.4 & 0.92 \\
T4 & 85 & 11.46 & 2.44 & 0.76 \\
\hline
\end{tabular}

Note. T1: Yellow Latosol; T2: Yellow Latosol + cattle manure (2:1); T3: Latosol yellow + organic compound (2:1); T4: Yellow latosol + liming.

It is observed that the treatments promoted changes in the composition of the substrates. The Yellow Latosol presented high acidity, which is characteristic of this type of common soil in the Amazon region, the other substrates presented $\mathrm{pH}$ in the ideal range (5.6 to 6.2) for most crops (Silva et al., 2016).

All treatments presented medium iron content and low amount of copper (Dadalton \& Fuliin, 2001) and high levels of phosphorus. Yellow Latosol + cattle manure presented higher levels of this last element. The Latosol substrate showed the lowest concentrations of calcium, magnesium and manganese when compared to the other substrates.

The highest amount of carbon, potassium, calcium and zinc was found in the substrates to which organic matter was added (Yellow Latosol + organic compound and Yellow Latosol + cattlemanure), the organic compound being richer in carbon than cattle manure.

Cattle manure, organic compost and liming, mixed with the Yellow Latosol, neutralized the aluminum that was in high concentration in this soil, reducing the potential acidity $(\mathrm{H}+\mathrm{Al})$, increasing the saturation of bases to levels appropriate to the crops (Dadalton \& Fuliin, 2001).

Similar results were found in the cultivation of castor bean (Ricinus communis L.) seedlings, which were abuded with bovine manure and organic compound favoring the growth of height, diameter and larger number of leaves (Fernandes, Chaves, Dantas, \& da Silva, 2009). Other works also prove that the addition of organic matter has an influence on soil structure modification, releasing nutrients and producing substances that stimulate growth (Miranda, Batista, Tucci, Almeira, \& Guimarães, 2013; Oliveira et al., 2014; Cerqueira, Freitas, Maciel, Carneiro, $\&$ Leite, 2015).

With the addition of organic matter in the substrate there is a rapid mineralization and supply of the chemical element phosphorus, limiting the growth of the species, and others, such as: carbon, nitrogen and sulfur (Gomes, Couto, Leite, Xavier, \& Garcia, 2002; Fernandes et al., 2009).

The relationship between height and diameter are routinely used as parameters in the quality evaluation of seedlings, since they reflect the accumulation of reserves by the plant, ensuring a higher resistance and a better fixation in the soil (Coelho, Miranda, Melo, \& Barbosa, 2015; Da Silva Neto et al., 2015).

The positive effect on the growth of Enterolobium contortisiliquum seedlings produced in substrates containing organic compound may be related to the higher concentration of nutrients in these substrates. This behavior represents a favorable characteristic for the production of sustainable seedlings with purpose of use in the productive chain, since it allows the substitution of the organic fertilizers, that can be acquired at low cost. Thus, 
it is satisfactory in terms of meeting the nutritional demand of the plants and viable from an economic and environmental point of view (Fernandes et al., 2009).

The use of this species in reforestation programs has shown efficiency in function of being a species adapted to several biomes and their economic importance from the point of view of the use for the shipbuilding pole, furniture and constructions, besides reforestation programs in degraded areas in the Amazon.

\section{Conclusion}

Enterolobium contortisiliquum responded to the addition of organic matter.

The substrate Yellow Latosol + organic compound provided the highest growth of Enterolobium contortisiliquum seedlings.

Organic compost and cattle manure increase the soil carbon, potassium, calcium and zinc contents.

The organic compound provides an indication for increased productivity of Enterolobium contortisiliquum.

Enterolobium contortisiliquum is a species with potential for production of sustainable seedlings with purpose of use in the productive chain and in recovery of degraded areas.

\section{References}

Brazil, Ministério da Agricultura e Reforma Agrária. (2009). Regras para análise de sementes. Escarificação Mecânica (p. 365). Brasília, DF: SNDA/DNDV/CLAV.

Carlos, L., Venturin, N. Macedo, R. L. G., Higashikawa, E. M., Garcia, M. B., \& Farias, E. S. (2014). Crescimento e nutrição mineral de mudas de pequi sob efeito da omissão de nutrientes. Ciência Florestal, 24(1), 13-21. https://doi.org/10.5902/1980509813318

Carvalho Filho, J. L. S., Blank, M. F. A., \& Blank, A. F. (2004). Produção de mudas de angelim (Andira fraxinifolia Benth.) em diferentes ambientes, recipientes e substratos. Revista Ciência Agronômica, 35(1), 61-67. Retrieved from http://www.ccarevista.ufc.br/site/down.php?arq=07rca35-1.pdf

Cerqueira, F. B., Freitas, G. A., Maciel, C. J.; Carneiro, J. S. S., \& Leite, R. C. (2015). Produção de mudas de tomate cv. Santa Cruz em diferentes substratos. Journal of Bioenergy and Food Science, 2, 39-45. https://doi.org/10.18067/jbfs.v2i2.21

CFSEMG (Comissão de Fertilidade do Solo do Estado de Minas Gerais). (1999). Recomendações para o uso de corretivos e fertilizantes em Minas Gerais: $5^{a}$ aproximação. Lavras.

Coelho, C. F., Miranda, I. P. A., Melo, Z. L. O., \& Barbosa, E. M. (2015). Physiological Behave of AcaiSeedlings (Euterpe precatoria MART.) under Increasing Levels of Irradiance. Journal of Agricultural Science, 7(3), 236-242. https://doi.org/10.5539/jas.v7n3p236

Coradin, L., Siminski, A., \& Reis, A. (2011). Espécies nativas da flora brasileira de valor econômico atual ou potencial: Plantas para o futuro-Região Sul (p. 934). Brasília, DF: Ministério do Meio Ambiente.

Da Silva Neto, O. P., Miranda, I. P. A., Barbosa, E. M., Melo, Z. L. O., Coelho, C. F., Ferreira, A. F. T., \& Miranda, T. A. (2015). Seedling Morphology of (Euterpe precatoria MART.) under Levels of Irradiance. Journal of Agricultural Science, 7(3), 198-202. https://doi.org/10.5539/jas.v7n10p198

Dadalto, G. G., \& Fullin, E. A. (2001). Manual de recomendação de calagem e adubação para o Estado do Espírito Santo: $4^{a}$ aproximação (pp. 184-185). Vitória, ES: SEEA/INCAPER.

Fernandes, J. D., Chaves, L. H. G., Dantas, J. P., \& Da Silva, J. R. P. (2009). Adubação orgânica e mineral no desenvolvimento da Mamoneira. Engenharia Ambiental, 6(2), 358-368. Retrieved from http://ferramentas. unipinhal.edu.br/engenhariaambiental/include/getdoc.php?id $=653 \&$ article $=261 \&$ mode $=$ pdf

Ferreira, M. G. R., Rocha, R. B., Gonçalves, E. P., Alves, E. U., \& Ribeiro, G. D. (2009). Influência do substrato no crescimento de mudas de cupuaçu (Theobroma grandiflorum Schum.). Acta Scientiarum. Agronomy, 31(4), 677-681. https://doi.org/10.4025/actasciagron.v31i4.3092

Furtini Neto, A. E., Vale, F. R., Faquin, V., \& Fernandes, L. A. (1999). Acidez do solo crescimento de algumas espécies arbóreas na fase de muda. Cerne, 5(2-12). Retrieved from http://www.bibliotecaflorestal.ufv.br:80/ handle/123456789/18286

Gomes, J. M., Couto, L., Leite, H. G., Xavier, A., \& Garcia, S. L. R. (2002). Sistemas de colheita e manejo da palhada de cana-de-açúcar. Pesquisa Agropecuária Brasileira, 40(3), 271-278. 
Hunt, R. (1982). Plant growth curves: The functional approach to plant growth analysis. Edward Arnold Publishers, London.

Lorenzi, H. (2002). Árvores brasileiras: Manual de identificação e cultivo de plantas arbóreas do Brasil (4th ed., Vol. 1, p. 368). Nova Odessa-SP: Editora Plantarum.

Miranda, J. F. M., Batista, I. M. P., Tucci, C. A. F., Almeida, N. O., \& Guimarães, M. A. (2013). Substrato para produção de mudas de Macacaúba (Platymiscium ulei Harms) no município de Autazes, AM. Ciência Florestal, 23(4), 555-562. https://doi.org/10.5902/1980509812339

Oliveira, L. B., Accioly, A. M. A., Santos, C. L. R., Flores, R. A., \& Barbosa, F. S. (2014). Características químicas do solo e produção de biomassa de alface adubada com compostos orgânicos. Revista Brasileira de Engenharia Agrícola e Ambiental, 18(2), 157-164. https://doi.org/10.1590/S1415-43662014000200005

Silva, A. M., Canuto, D. S. O., Alves, M. C., Buzetti, S., Moraes, M. L. T., \& Sakamoto, A. Y. (2016). Características químicas de um latossolo vermelho em recuperação sob plantio de Pinus spp. Ciência Florestal, 26(4), 1049-1060. https://doi.org/10.5902/1980509824994

Silva, A. R. M. da., Tucci, C. A. F., Lima, H. N., Souza, P. A. de, \& Venturin, N. (2007). Efeito de doses crescentes de calcário na produção de mudas de sumaúma (Ceiba pentandra L. Gaertn). Floresta, 38(2), 295-302. Retrieved from http://revistas.ufpr.br/floresta/article/download/11623/8158

Silva, F. de A. S., \& Azevedo, C. A. V. de. (2009). Principal Components Analysis in the Softwar Assistat-statistical Attendance. World Congress on Computers in Agriculture, 7 Reno-NV-USA: American Society of Agricultural and Biological Engineers. Retrieved from http://www.assistat.com/indexp.html

Tucci, C. A. F., Lima, H. N., \& Lessa, J. F. (2009). Adubação nitrogenada na produção de mudas de mogno (Swietenia macrophylla King.). Acta Amazônica, 39(2), 289-294. https://doi.org/10.1590/S0044-59672009 000200007

Zenero, M. D. O., Silva, L. F. S. da, Castilho, S. C. P., Vidal, A., Grimaldi, M., \& Cooper, M. (2016). Characterization and Classification of Soils under Forest and Pasture in an Agroextractivist Project in Eastern Amazonia. Revista Brasileira de Ciência do Solo, 40. https://doi.org/10.1590/18069657rbcs 20160165

\section{Copyrights}

Copyright for this article is retained by the author(s), with first publication rights granted to the journal.

This is an open-access article distributed under the terms and conditions of the Creative Commons Attribution license (http://creativecommons.org/licenses/by/4.0/). 